\title{
Efficacy and safety of cumaru syrup as complementary therapy in mild persistent asthma: a double-blind, randomized, placebo-controlled study
}

\author{
Elisete Mendes Carvalho, Gilmara Holanda da Cunha, Francisco Vagnaldo Fechine, \\ Célia Regina Amaral Uchôa, Manoel Odorico de Moraes Filho, Fernando Antônio Frota Bezerra, \\ Maria Elisabete Amaral de Moraes*
}

Clinical Pharmacology Unit, Department of Physiology and Pharmacology, School of Medicine, Federal University of Ceará

\begin{abstract}
Amburana cearensis is a medicinal plant known as "cumaru". It is used in Northeast Brazil in the treatment of respiratory diseases. This was a randomized, double-blind, placebo-controlled study, with the aim of evaluating the efficacy and safety of cumaru syrup as complementary therapy in mild persistent asthma. The study consisted of 3 phases, pre-treatment, treatment and post-treatment. The primary efficacy outcome was comparison of the changes reported by patients of the cumaru and placebo groups after treatment, using the "Asthma Quality of Life Questionnaire" (AQLQ). The secondary outcome was the effect of cumaru syrup on lung function based on spirometry. The results showed that in the cumaru group, the proportion of patients who had global improvement in asthma symptoms was significantly greater $(61.90 \%, \mathrm{P}=0.0009)$ than in the placebo group $(9.52 \%)$. Only the spirometric parameters Forced Vital Capacity $(\mathrm{FVC})$ and Forced Expiratory Volume in 1 second $\left(\mathrm{FEV}_{1}\right)$ showed significant intergroup differences in post-treatment $(\mathrm{P}<0.05)$. The hematological and serum chemistry tests performed in the pre-treatment and post-treatment showed no statistically significant differences $(\mathrm{P}>0.05)$. Adverse events were reported by 3 patients (14.29\%) in the cumaru group and 3 patients $(14.29 \%)$ in the placebo group. All adverse events were considered non-serious and mild.
\end{abstract}

Uniterms: Amburana cearensis/phytoterapy. Cumaru syrup/efficacy. Asthma/treatment.

\begin{abstract}
Amburana cearensis é uma planta medicinal conhecida como "cumaru". No Nordeste do Brasil é usada no tratamento de doenças respiratórias. Este é um estudo randomizado, duplo-cego e controlado por placebo, com o objetivo de avaliar a eficácia e segurança do xarope de cumaru como terapia complementar da asma persistente leve. O estudo consistiu de três fases, pré-tratamento, tratamento e pós-tratamento. A variável primária para determinação da eficácia foi a comparação das mudanças referidas pelos pacientes dos grupos cumaru e placebo após o tratamento, usando o "Questionário sobre Qualidade de Vida na Asma" (QQVA). A variável secundária foi o efeito do xarope de cumaru na função pulmonar baseado na espirometria. Os resultados mostraram que no grupo cumaru, a proporção de pacientes com melhora global dos sintomas da asma foi significativamente maior $(61,90 \%, \mathrm{P}=0.0009)$ que no grupo placebo $(9,52 \%)$. Somente os parâmetros espirométricos, capacidade vital forçada (CVF) e volume expiratório forçado no primeiro segundo $\left(\mathrm{VEF}_{1}\right)$, mostraram diferença intergrupo significtivas no pós-tratamento $(\mathrm{P}<0.05)$. Os testes hematológicos e do soro realizados no pré-tratamento e pós-tratamento não mostraram diferenças estatisticamente significativas $(\mathrm{P}>0.05)$. Eventos adversos foram reportados por 3 pacientes $(14,29 \%)$ no grupo cumaru e $3(14,29 \%)$ no grupo placebo. Todos os eventos adversos foram não sérios e leves.
\end{abstract}

Unitermos: Amburana cearensis/fitoterapia. Xarope de Cumaru/eficácia. Asma/tratamento.

\footnotetext{
*Correspondence: M. E. A. Moraes. Unidade de Farmacologia Clínica, Departmento de Fisiologia e Farmacologia, Faculdade de Medicina, Universidade Federal do Ceará. Rua Coronel Nunes de Melo, 1127, 60430-270 - Fortaleza - Ceará, Brasil. E-mail: gpclinica@unifac.med.br
} 


\section{INTRODUCTION}

Asthma is a chronic inflammatory disease and a global health problem affecting around 300 million individuals of all ages, ethnic groups and countries. It is estimated that around 250,000 people die prematurely each year as a result of asthma (Bousquet et al., 2010). Several classes of medicines are indicated in the treatment of asthma (Patel et al., 2010; GINA, 2008; Gerald et al., 2008). On the other hand, the use of complementary and alternative medicine is becoming more common, mainly in the last decades (Metcalfe et al., 2010; Cunha et al., 2011). Herbal products, even though in prevalent use, are of uncertain value in the treatment of asthma, and only randomized controlled trials can truly determine efficacy (Passalacqua et al., 2005; Mega et al., 2011).

Amburana cearensis A. C. Smith, Fagaceae, is a medicinal plant commonly known as "cumaru," which is used in Northeast Brazil as an anti-inflammatory and spasmolytic medication and also in the treatment of respiratory tract diseases (Leal et al., 2003a). A toxicological study of the hydroalcoholic extract of $A$. cearensis in rats, administered sub-chronically and during pregnancy, showed that an oral dose of $500 \mathrm{mg} / \mathrm{kg}$ did not cause toxic effects, suggesting that it could be used with reasonable safety in pharmaceutical preparations such as "cumaru syrup" (Leal et al., 2003b).

Pre-clinical studies have examined the relaxing action of the hydroalcoholic extract of $A$. cearensis in tracheal smooth muscle pre-contracted by carbachol, histamine and $\mathrm{KCl}$, demonstrating that the hydroalcoholic extract and chemical constituents of $A$. cearensis have anti-inflammatory as well as smooth muscle relaxant activities, justifying traditional uses of the plant as a bronchodilator in the treatment of respiratory tract diseases (Leal et al., 2003a, 2010). Anti-inflammatory effects can be explained, at least in part, by the ability of these compounds to reduce neutrophil degranulation, myeloperoxidase activity, as well as TNF-alpha secretion (Leal et al., 2009).

The large-scale use of wild $A$. cearensis as a medicinal plant, and in the formulation of cumaru syrup by Governmental Programs of Phytotherapy, in Northeast Brazil, and by the local pharmaceutical industry, justifies a study in humans. Cumaru syrup has a low cost and has been widely used indiscriminately by people with asthma, but its efficacy has yet to be proven through clinical trials. Thus, the aim of the present study was to investigate the therapeutic efficacy and safety of cumaru syrup as complementary therapy in mild persistent asthma.

\section{METHODS}

\section{Patients}

This study was conducted in accordance with the Declaration of Helsinki and the protocol was approved by the Ethics Committee of the Federal University of Ceará, in Fortaleza, Brazil, with registration number 169/07. All patients gave their signed informed consent and were free to withdraw from the trial at any time.

Patients were selected at the outpatient clinics of the Doctor Carlos Alberto Gomes Studart Hospital and Walter Cantídio University Hospital, both references in the treatment of pulmonary diseases. These patients had mild persistent asthma controlled and were enrolled in the National Asthma Control Program promoted by the Ministry of Health in each institution. The patients were recruited for the Clinical Pharmacology Unit and submitted to a health evaluation by a doctor and physiotherapist.

The criteria for inclusion in the study were as follows: male or female patients, aged 18 years and older, confirmed diagnosis of mild persistent asthma controlled in accordance with the criteria of Global Initiative for Asthma - GINA (GINA, 2008), and currently receiving inhaled corticosteroid medication at a total daily dose of 250-750 $\mu \mathrm{g}$ beclomethasone dipropionate regularly by at least three weeks, combined or not with inhaled beta-2-adrenergic agonist (salbutamol) for short times. Exclusion criteria included hypersensitivity to the study drug, addiction to drugs and smoking, use of experimental drugs in the previous 6 months, laboratory tests showing clinical abnormalities, untreated illnesses, pregnancy, and breast-feeding.

Female patients of child-bearing potential were included after confirmation of a negative pregnancy test ( $\beta$-subunit of human chorionic gonadotropin - HCG), and were recommended to use highly effective methods of birth control contraceptives during the study, such as oral contraceptive and condom, intra-uterine device (IUD) and condom or diaphragm with spermicide and condom.

\section{Study design}

This was a randomized, double-blind, placebocontrolled study, with the aim of evaluating the efficacy of cumaru syrup as complementary therapy in mild persistent asthma. The study consisted of 3 phases, pre-treatment, treatment and post-treatment.

During pre-treatment, the patients signed an informed consent form. Physical examination and electrocardiogram were performed and the diagnosis of mild 
persistent asthma was confirmed. We also monitored body mass index (BMI), systolic blood pressure, diastolic blood pressure and heart rate after $30 \mathrm{~min}$ of rest in sitting position. Spirometry was measured (COSMED Pony FX) and the questionnaire was administered: "Juniper Asthma Quality of Life Questionnaire" (AQLQ) (Juniper et al., 1992). The treatment phase consisted of randomization and administration three times a day for fifteen days of $15.0 \mathrm{~mL}$ of cumaru syrup or placebo. Randomization and distribution of the cumaru syrup were performed by a pharmacist who has not evaluated the effectiveness of the product in the patients. The blind code was broken after the study for analysis of efficacy variables by a statistician. The post-treatment consisted of evaluation of the patient following cumaru syrup or placebo administration, including spirometry and administration of AQLQ.

\section{Cumaru syrup}

Cumaru syrup is produced by the Scholl Pharmacy Laboratory of the Federal University of Ceará, located in Fortaleza, Brazil. Trunk bark of wild adult $A$. cearensis was collected in Fortaleza, Ceará State, Northeast Brazil. Voucher specimens ( $\mathrm{n}^{\circ} .837$ and 847$)$ were deposited at the Prisco Bezerra Herbarium, Department of Biology of the Federal University of Ceará.

The collected fresh plant material (trunk bark) was dried and immediately ground and submitted to extraction with water/ethanol (4:1), by mechanical stirring at room temperature $\left(22^{\circ} \mathrm{C}\right)$ for $24 \mathrm{~h}$. Ethanol was evaporated away and the volume adjusted to the concentration needed, just before use. The yield was $12 \%$, based on solid residues. The hydroalcoholic extract obtained was analyzed by HPLC according the method previously described (Canuto, Silveira, 2006; Canuto, 2007). The chemical constituents (vanillic acid, coumarin, protocatechuic acid and amburoside A) were isolated as described in a previous work (Canuto, Silveira, 2010).

Cumaru syrup contains $100 \mathrm{~mL}$ of simple essential syrup and 5\% hydroalcoholic extract of $A$. cearensis, containing $0.15 \mathrm{mg} / \mathrm{mL}$ coumarin. The placebo was composed of only the simple essential syrup. The product characteristics were: slightly cloudy and yellowish color; sweet aroma; and viscosity, density and $\mathrm{pH}$ respectively $43.8 \mathrm{cP}, 1.2379 \mathrm{~g} / \mathrm{mL}$ and 6.0 for cumaru syrup and 44.0 $\mathrm{cP}, 1.2410 \mathrm{~g} / \mathrm{mL}$ and 6.3 for placebo.

\section{Primary and secondary efficacy variables}

The primary outcome was comparisons of the changes reported by patients of the cumaru and placebo groups after the treatment, by questionnaire "Asthma Quality of Life Questionnaire" (AQLQ).

This instrument is an asthma-specific questionnaire with 32 items, which provides an Overall Summary Index and assesses four domains of health-related quality of life, namely symptoms, activity limitations, environmental stimulus and emotional function, during the 2 weeks of treatment (Juniper et al., 1992). The response options for each of the 32 items are on a 7-point scale, ranging from 1 (totally limited) to 7 (not at all limited). AQLQ has been shown to be sensitive to change in health-related quality of life. A change in score of 0.5 points has been determined to be the minimally important difference (Juniper et al., 1994).

The secondary outcome was the effect of cumaru syrup on lung function based on spirometry. Forced vital capacity (FVC), peak expiratory flow (PEF), forced expiratory volume in 1 second $\left(\mathrm{FEV}_{1}\right)$, forced expiratory flow between 25 and $75 \%$ (FEF 25-75\%) and the relation $\left(\mathrm{FEV}_{1} / \mathrm{FVC}\right)$ were measured in pre-treatment and posttreatment.

\section{Safety and tolerability}

Patients in the cumaru and placebo groups were asked to record any adverse events in their diary during the treatment. Adverse events were mapped to preferred terms and body systems and coded using the Adverse Reaction Terminology Dictionary of the World Health Organization (WHO, 2004).

Hematological and serum chemistry tests were evaluated in pre-treatment and post-treatment in the cumaru and placebo groups. Tests were performed for determination of hemoglobin, red blood cells, hematocrit, platelets, leukocytes, lymphocytes, basophils, eosinophils, monocytes, neutrophils, prothrombin time (PT), activated partial thromboplastin time (APTT), glucose, creatinine, urea, serum glutamic oxaloacetic transaminase (aspartate aminotransferase - AST), and serum glutamic pyruvic transaminase (alanine aminotransferase - ALT), as well as HCG $\beta$-subunit in female patients of child-bearing potential.

Analyses were performed at a local accredited laboratory. When values for a given sample were outside the normal range, the analysis was repeated to confirm the findings. Abnormal values were recorded by the investigator on the case report form and an assessment was made of their likely etiology.

\section{Statistical analysis}

The quantitative variables were initially analyzed 
by the Kolmogorov-Smirnov test to verify the normality of distribution. For descriptive statistics, the mean and standard deviation (parametric data) or median, interquartile range and minimum and maximum values (nonparametric data) were calculated. Comparisons between groups (placebo versus cumaru) in each phase were made using unpaired $t$ test (parametric data) or Mann-Whitney $U$ test (nonparametric variables). Comparisons between the two phases (pre-treatment and post-treatment) in the same group were performed using paired $t$ test (parametric data) or Wilcoxon test (nonparametric variables). Nominal qualitative variables were expressed as absolute and relative frequency and analyzed by Fisher's exact test. Ordinal qualitative variables were expressed as median, interquartile range and minimum and maximum values and analyzed by the Mann-Whitney $U$ test. The significance level was set at $0.05(5 \%)$ and a P-value less than 0.05 was accepted as statistically significant. The statistical software GraphPad Prism ${ }^{\circledR}$ version 5.00 was used for data processing and designing of the graphs.

\section{RESULTS}

Of the 67 patients initially evaluated, only 47 met the inclusion criteria. Twenty-five patients were randomized to receive cumaru syrup and 22 to receive placebo. Four patients in the cumaru and one in the placebo group were lost to follow-up and so were withdrawn from the trial due to a deviation from the experimental protocol. Patient demographics and pre-treatment characteristics were very similar for the cumaru and placebo groups, except for the age, which was higher in the cumaru group, showing a statistically significant difference $(\mathrm{P}=0.0054)$ (Table I).

The mean total individual AQLQ scores of the placebo and cumaru groups in the pre-treatment and post-treatment phases are shown in Table II. A statistically significant association was observed between the type of treatment employed and the global improvement in mild persistent asthma. In the cumaru group, the proportion of patients who had global improvement in asthma was significantly greater $(61.90 \%, \mathrm{P}=0.0009)$ than in the placebo group $(9.52 \%)$, with a relative risk of 6.50 (95\% confidence interval: 1.67 to 25.34 ), which means that patients treated with cumaru syrup were 6.5 times more likely to have an improvement in their asthma clinical status than the patients treated with placebo (Table III).

In the evaluation of lung function, only the spirometric parameters forced vital capacity (FVC) and expiratory volume in 1 second $\left(\mathrm{FEV}_{1}\right)$, both in liters, showed intergroup significance in post-treatment $(\mathrm{P}<0.05)$. However, these changes were not considered clinically significant, because it existed prior to treatment, although no statistical significance (Table IV).

The hematological and serum chemistry tests performed in pre-treatment and post-treatment showed no statistically significant differences $(\mathrm{P}>0.05)$ (Table V). Adverse events were reported by three patients (14.29\%) in the cumaru group and three patients $(14.29 \%)$ in the placebo group. The adverse events were dizziness, headache and nausea. There were no significant differences between

TABLE I - Demographics and pre-treatment characteristics for patients of Placebo and Cumaru groups. Data expressed as relative frequency or mean \pm standard deviation

\begin{tabular}{lcc}
\hline Characteristic & Placebo group & Cumaru group \\
\hline Number of patients & 21 & 21 \\
\hline Sex & Male $=5 / 21(23.8 \%)$ & Male $=3 / 21(14.2 \%)$ \\
& Female $=16 / 21(76.1 \%)$ & Female $=18 / 21(85.7 \%)$ \\
Age (years) & $37.2 \pm 10.3$ & $46.6 \pm 10.3 *$ \\
BMI $\left(\mathrm{kg} / \mathrm{m}^{2}\right)$ & $26.3 \pm 4.1$ & $27.2 \pm 4.3$ \\
Systolic blood pressure $(\mathrm{mmHg})$ & $117.5 \pm 16.8$ & $121.1 \pm 15.9$ \\
Diastolic blood pressure $(\mathrm{mmHg})$ & $82.2 \pm 9.5$ & $82.3 \pm 8.8$ \\
Mean blood pressure (mmHg) & $93.9 \pm 11.3$ & $95.3 \pm 10.7$ \\
FEV $(\%)$ & $82.9 \pm 17.3$ & $83.4 \pm 25.0$ \\
PEF $(\%)$ & $71.4 \pm 18.9$ & $73.5 \pm 26.3$ \\
Use of rescue medication & $20 / 21(95.2 \%)$ & $19 / 21(90.4 \%)$ \\
Mean total AQLQ score & $4.5 \pm 1.1$ & $4.3 \pm 1.1$ \\
\hline
\end{tabular}

$* \mathrm{P}=0.0054$ versus placebo group. 
TABLE II - AQLQ domains scores and AQLQ global score for Placebo and Cumaru groups in pre-treatment and post-treatment phases, expressed as mean \pm standard deviation

\begin{tabular}{lcccccc}
\hline \multirow{2}{*}{ Domain } & \multicolumn{3}{c}{ Pre-treatment } & \multicolumn{3}{c}{ Post-treatment } \\
\cline { 2 - 7 } & Placebo group & Cumaru group & $P$ value $^{1}$ & Placebo group & Cumaru group & $P$ value $^{1}$ \\
\hline Symptoms & $4.94 \pm 1.38$ & $4.57 \pm 1.38$ & 0.3966 & $4.83 \pm 1.20$ & $6.21 \pm 0.60 \dagger$ & $<0.0001$ \\
Activity limitations & $4.12 \pm 0.94$ & $4.04 \pm 1.13$ & 0.7986 & $4.38 \pm 1.01$ & $5.86 \pm 0.78 \dagger$ & $<0.0001$ \\
Environment stimulus & $3.98 \pm 1.49$ & $3.71 \pm 1.45$ & 0.5674 & $4.51 \pm 1.99$ & $5.61 \pm 1.35 \dagger$ & 0.0431 \\
Emotional function & $4.78 \pm 1.55$ & $4.75 \pm 1.72$ & 0.9552 & $4.99 \pm 1.48$ & $6.25 \pm 1.03 \dagger$ & 0.0028 \\
Mean total AQLQ score & $4.51 \pm 1.14$ & $4.31 \pm 1.20$ & 0.5770 & $4.66 \pm 1.13$ & $6.02 \pm 0.74 \dagger$ & $<0.0001$ \\
\hline
\end{tabular}

${ }^{1}$ Intergroup significance. $\uparrow \mathrm{P}<0.0001, \pm \mathrm{P}=0.0003$ in relation to pre-treatment phase in the same group.

TABLE III - Global improvement of mild persistent asthma observed in Cumaru and Placebo groups, which was defined as an increase of at least 0.5 in all AQLQ domains, as well as in the AQLQ global score

\begin{tabular}{lccc}
\hline \multirow{2}{*}{ Group } & \multicolumn{2}{c}{ Global improvement of asthma } & \multirow{2}{*}{ Total } \\
\cline { 2 - 3 } & Presence & Absence & \\
\hline Cumaru & $\mathbf{1 3 ( 6 1 . 9 0 \% ) \dagger}$ & 8 & 21 \\
Placebo & $\mathbf{2 ( 9 . 5 2 \% )}$ & 19 & 21 \\
Total & 15 & 27 & 42
\end{tabular}

$\dagger \mathrm{P}=0.0009$ (Fisher's exact test).

the proportion of patients who had adverse events in the cumaru and the placebo groups, demonstrating safety in the use of cumaru syrup. All adverse events were considered non-serious and of mild intensity. No patient was withdrawn from the study due to adverse events.

\section{DISCUSSION}

This randomized study evaluated the efficacy and safety of cumaru syrup as complementary therapy in mild persistent asthma. Based on a placebo-controlled and double-blind design, it was observed that this phytotherapeutic product was safe and caused a significant improvement in the patients with mild persistent asthma.

Pre-clinical studies have shown that the hydroalcoholic extract of $A$. cearensis has anti-inflammatory and smooth muscle relaxant activities, justifying traditional uses of the plant as bronchodilator in the treatment of respiratory tract diseases (Leal et al., 2003a). Furthermore, previous studies reported antinociceptive and antioxidant properties of the hydroalcoholic extract and chemical constituents of this plant (Leal et al., 2009; Leal et al., 2005).

Several compounds have been isolated from the trunk bark of $A$. cearensis, including coumarin (1,2-ben-

TABLE IV - Evaluation of lung function in the patients of Placebo and Cumaru groups, according to spirometric parameters. The data correspond to mean and standard deviation of measurements made in the in pre-treatment and post-treatment phases

\begin{tabular}{|c|c|c|c|c|c|c|}
\hline \multirow{2}{*}{$\begin{array}{l}\text { Spirometric } \\
\text { parameters }\end{array}$} & \multicolumn{3}{|c|}{ Pre-treatment } & \multicolumn{3}{|c|}{ Post-treatment } \\
\hline & Placebo & Cumaru & $P$ value $^{1}$ & Placebo & Cumaru & $P$ value $^{1}$ \\
\hline FVC (\%) & $98.28 \pm 10.99$ & $99.37 \pm 23.90$ & 0.85 & $102.37 \pm 11.66$ & $98.40 \pm 24.16$ & 0.50 \\
\hline FVC (L) & $3.30 \pm 0.51$ & $2.92 \pm 0.96$ & 0.12 & $3.43 \pm 0.69$ & $2.91 \pm 0.90$ & 0.04 \\
\hline PEF (\%) & $71.46 \pm 18.95$ & $73.53 \pm 26.32$ & 0.77 & $74.50 \pm 19.04$ & $76.05 \pm 31.11$ & 0.84 \\
\hline $\mathrm{PEF}(\mathrm{L} / \mathrm{s})$ & $4.7 \pm 1.09$ & $4.47 \pm 1.61$ & 0.50 & $5.22 \pm 1.16$ & $4.54 \pm 1.82$ & 0.16 \\
\hline $\mathrm{FEV}_{1}(\%)$ & $82.97 \pm 17.35$ & $83.45 \pm 25.02$ & 0.94 & $86.04 \pm 17.32$ & $82.30 \pm 23.09$ & 0.55 \\
\hline $\mathrm{FEV}_{1}(\mathrm{~L})$ & $2.33 \pm 0.42$ & $2.05 \pm 0.73$ & 0.13 & $2.42 \pm 0.50$ & $2.01 \pm 0.66$ & 0.02 \\
\hline FEF 25-75\% (\%) & $62.73 \pm 30.52$ & $60.87 \pm 31.34$ & 0.84 & $64.12 \pm 29.22$ & $59.62 \pm 31.92$ & 0.63 \\
\hline FEF $25-75 \%(\mathrm{~L} / \mathrm{s})$ & $2.05 \pm 1.05$ & $1.62 \pm 0.84$ & 0.15 & $2.06 \pm 0.95$ & $1.57 \pm 0.82$ & 0.08 \\
\hline $\mathrm{FEV}_{1} / \mathrm{FVC}$ & $84.40 \pm 16.49$ & $83.60 \pm 14.85$ & 0.86 & $84.48 \pm 16.61$ & $83.85 \pm 13.70$ & 0.89 \\
\hline
\end{tabular}

${ }^{1}$ Intergroup significance. 
TABLE V - Results of hematological and serum chemistry tests for Placebo and Cumaru groups in pre-treatment and post-treatment phases. Data expressed as mean \pm standard deviation or median and interquartile range

\begin{tabular}{|c|c|c|c|c|c|}
\hline \multirow{2}{*}{ Parameters } & \multicolumn{2}{|c|}{ Placebo group } & \multicolumn{2}{|c|}{ Cumaru group } & \multirow{2}{*}{ Reference range } \\
\hline & Pre-treatment & Post-treatment & Pre-treatment & Post-treatment & \\
\hline Hemoglobin & $13.75 \pm 1.28$ & $13.69 \pm 1.08$ & $13.47 \pm 0.73$ & $13.60 \pm 1.06$ & $\begin{array}{c}\text { Male: } 12.8-17.8 \mathrm{~g} / \mathrm{dL} \\
\text { Female: } 11.5-16.4 \mathrm{~g} / \mathrm{dL}\end{array}$ \\
\hline Red blood cells & $4.70 \pm 0.39$ & $4.64 \pm 0.32$ & $4.68 \pm 0.26$ & $4.70 \pm 0.36$ & $\begin{array}{l}\text { Male: } 4.5-6.1 \text { million } / \mathrm{mm}^{3} \\
\text { Female: } 4.1-5.3 \text { million } / \mathrm{mm}^{3}\end{array}$ \\
\hline Hematocrit & $41.53 \pm 3.07$ & $41.05 \pm 2.75$ & $41.33 \pm 2.35$ & $41.27 \pm 3.05$ & $\begin{array}{c}\text { Male: } 40.0 \%-54.0 \% \\
\text { Female: } 36.0 \%-48.0 \%\end{array}$ \\
\hline Platelets & $267.85 \pm 50.59$ & $268.76 \pm 41.04$ & $279.61 \pm 61.49$ & $268.55 \pm 50.64$ & $150-45010^{3} / \mathrm{mm}^{3}$ \\
\hline Leukocytes & $7.34 \pm 2.38$ & $6.84 \pm 2.74$ & $7.10 \pm 1.55$ & $7.15 \pm 1.58$ & $3.6-1110^{3} / \mathrm{mm}^{3}$ \\
\hline Lymphocytes & $29.76 \pm 7.12$ & $28.66 \pm 7.85$ & $27.61 \pm 6.02$ & $27.11 \pm 4.41$ & $20-50 / \mathrm{mm}^{3}$ \\
\hline Basophils & $0.00(0.00-1.00)$ & $1.00(0.00-1.00)$ & $0.00(0.00-1.00)$ & $0.00(0.00-1.00)$ & $0-3 / \mathrm{mm}^{3}$ \\
\hline Eosinophils & $4.00(3.00-6.00)$ & $4.00(2.00-6.00)$ & $3.00(2.00-6.00)$ & $2.50(2.00-5.00)$ & $1-6 / \mathrm{mm}^{3}$ \\
\hline Monocytes & $7.42 \pm 2.48$ & $7.57 \pm 1.85$ & $8.05 \pm 1.86$ & $8.66 \pm 2.00$ & $2-10 / \mathrm{mm}^{3}$ \\
\hline Neutrophils & $57.42 \pm 8.38$ & $58.38 \pm 9.80$ & $59.05 \pm 5.37$ & $59.16 \pm 5.58$ & $45-70 / \mathrm{mm}^{3}$ \\
\hline PT & $108.11 \pm 14.89$ & $107.91 \pm 12.48$ & $106.50 \pm 9.74$ & $107.61 \pm 27.37$ & $\geq 70 \%$ \\
\hline APTT & $0.98 \pm 0.17$ & $0.98 \pm 0.12$ & $0.96 \pm 0.11$ & $0.94 \pm 0.10$ & $\leq 1.20$ \\
\hline Glucose & $81.42 \pm 11.46$ & $84.71 \pm 13.42$ & $84.33 \pm 14.9$ & $87.38 \pm 15.77$ & $70-99 \mathrm{mg} / \mathrm{dL}$ \\
\hline Creatinine & $0.75 \pm 0.16$ & $0.73 \pm 0.14$ & $0.73 \pm 0.12$ & $0.69 \pm 0.14$ & $0.6-1.2 \mathrm{mg} / \mathrm{dL}$ \\
\hline Urea & $26.56 \pm 6.29$ & $24.59 \pm 6.17$ & $27.03 \pm 6.88$ & $24.76 \pm 6.11$ & $10-50 \mathrm{mg} / \mathrm{dL}$ \\
\hline AST & $24.29 \pm 9.13$ & $23.37 \pm 8.07$ & $19.68 \pm 3.79$ & $20.17 \pm 3.99$ & $\begin{array}{c}\text { Male: } \leq 38 \mathrm{U} / \mathrm{L} \\
\text { Female: } \leq 32 \mathrm{U} / \mathrm{L}\end{array}$ \\
\hline ALT & $24.16 \pm 13.59$ & $22.31 \pm 10.16$ & $19.64 \pm 9.04$ & $19.16 \pm 8.74$ & $\begin{array}{c}\text { Male: } \leq 41 \mathrm{U} / \mathrm{L} \\
\text { Female: } \leq 31 \mathrm{U} / \mathrm{L}\end{array}$ \\
\hline
\end{tabular}

For all parameters analyzed, no significant differences $(\mathrm{P}>0.05)$ were found between Placebo and Cumaru groups in each phase or between pre-treatment and post-treatment phases in the same group.

zopyrone), its main constituent, plus isokaempferide (4',5,7-trihydroxyflavone), fisetin (3,5,3', 4'-tetrahydroxyflavone) and alfalone (6-hydroxy-4',7-dimethoxyisoflavone) (Canuto, Silveira, 2006). From the seeds of this plant, a Bowman-Birk trypsin inhibitor was isolated and purified. It was demonstrated that this inhibitor prolongs the blood clotting time of the contact phase activation pathway by inhibition of FXIIa (Tanaka et al., 1997).

Asthma is a common chronic inflammatory disease. Asthma cannot be cured, but appropriate management can control the disorder and enable people to enjoy a good quality of life. Identifying and treating impaired healthrelated quality of life is now recognized as an important component of asthma management (Juniper et al., 2004).

The primary outcome of the study was the score on the "Asthma Quality of Life Questionnaire" (AQLQ). With an individual patient change in AQLQ score of 0.5 signifying a clinically relevant change in health status
(Guyatt et al., 1998), 61.90\% of the subjects improved with cumaru syrup, and $9.52 \%$ improved with placebo. The secondary outcome of the study was lung function according to spirometry, where only FVC (L) and $\mathrm{FEV}_{1}$ (L) showed intergroup significance in post-treatment.

International guidelines state that treatments should not only improve asthma clinical status, and thus reduce the risk of exacerbations and possibly airway remodelling, but should also enable patients to feel and function better in their day-to-day lives (Juniper et al., 2004). Asthma-specific quality of life questionnaires have been developed and validated so that this aspect of patient management can be accurately measured and treatment effectiveness assessed. These questionnaires are now used in both clinical trials and clinical practice alongside the more traditional clinical measures of airway status, such as airway caliber, symptoms and markers of inflammation (Juniper et al., 2002). 
In another study that evaluated the effectiveness of the herbal medicine called AKLI, which contains the phytochemical component of Picrorrhiza kurroa, and extracts of Zingiber officinale and Ginkgo biloba, similar results as in the present study were also obtained; the efficacy was satisfactory in accordance with the AQLQ, but no statistically significant changes were found in lung function by spirometry data (Thomas et al., 2007). Other studies also demonstrated the effectiveness of herbal medicines as complementary therapy in asthma (Kelly-Pieper et al., 2009; Wong et al., 2009; Zhou et al., 2009).

The clinical examinations, physical evaluation and laboratory tests performed before and after the research did not show evidence of toxicity in the several organs and systems assessed. The adverse events reported for cumaru group and placebo group were all classified as non-serious and mild. These events did not result in any withdrawal from the trial. Preclinical toxicology studies in rats have shown that a hydroalcoholic extract of $A$. cearensis administered sub-chronically and during pregnancy in an oral dose of $500 \mathrm{mg} / \mathrm{kg}$, did not cause toxic effects and did not modify the biochemical and hematological profiles of the animals after treatment, indicating that extracts of $A$. cearensis can be used with reasonable safety in pharmaceutical preparations such as cumaru syrup. The clinical toxicology study of a herbal medicine formulation of Torresea cearensis (cumaru) in healthy volunteers concluded that clinical, electrocardiography and laboratory tests did not show any evidence of toxic signs in the various organs and systems studied (Soares et al., 2007).

There were difficulties in comparing the results obtained in other studies due to the existence of only preclinical studies of efficacy with A. cearensis. This clinical trial is the first study to evaluate the efficacy and safety of cumaru syrup in the treatment of mild persistent asthma in humans. It is concluded that this phytotherapeutic medication showed a significant beneficial effect, representing an alternative for the complementary therapy of asthma.

Finally, we suggest conducting further studies with larger samples of volunteers and period of prolonged treatment to observe the efficacy, toxicology and safety of the cumaru syrup because asthma is a chronic inflammatory disease. We consider the difficulties encountered in efficacy studies, lack of follow-up, high cost, accessibility of patients, among other things. After confirming their therapeutic efficacy and safety through clinical trials, phytotherapeutic medicines can be of great economic, medicinal, and social importance, when produced with rigorous quality control and used properly by patients.

\section{REFERENCES}

BATEMAN, E.D.; HURD, S.S.; BARNES, P.J.; BOUSQUET, J.; DRAZEN, J.M.; FITZGERALD, M. Global strategy for asthma management and prevention. GINA Executive Summary. Eur. Respir. J., v.31, n.1, p.143-178, 2008.

BOUSQUET, J.; MANTZOURANIS, E.; CRUZ, A.A.; AÏTKHALED, N.; BAENA-CAGNANI, C.E.; BLEECKER, E.R. Uniform definition of asthma severity, control, and exacerbations: Document presented for the World Health Organization Consultation on Severe Asthma. J Allergy Clin. Immunol., v.126, n.5, p.926-938, 2010.

CANUTO, K.M. Chemical aspects of interdisciplinary study (chemistry, pharmacology, agronomy) from A. cearensis A. C. Smith, 2007. 303p. [Thesis of PhD degree. Faculty of Medicine, Federal University of Ceará].

CANUTO, K.M.; SILVEIRA, E.R. Chemical constituents of trunk bark of Amburana cearensis A. C. Smith. Quím. Nova, v.29, n.6, p.1241-1243, 2006.

CANUTO, K.M.; SILVEIRA, E.R. Estudo fitoquímico de espécimes cultivadas de cumaru (Amburana cearensis A. C. SMITH). Quim. Nova, v.33, n.3, p.662-666, 2010.

CUNHA, G.H.; FECHINE, F.V.; SANTOS, L.K.X.; PONTES, A.V.; OLIVEIRA, J.C.; MORAES, M.O. Efficacy of the tincture of jalapa in the treatment of functional constipation: a double-blind, randomized, placebo-controlled study. Contemp. Clin. Trials, v.32, n.2, p.153-159, 2011.

GERALD, L.B.; MCCLURE, L.A.; HARRINGTON, K.F.; MANGAN, J.M.; GIBSON, L.; ATCHISON, J.; GRAD, R. Design of the supervised asthma therapy study: Implemeting an adherence intervention in urban elementary schools. Contemp. Clin. Trials, v.29, n.2, p.304-310, 2008.

GUYATT, G.H.; JUNIPER, E.F.; WALTER, S.D.; GRIFFITHS, L.E.; GOLDSTEIN, R.S. Interpreting treatment effects in randomized trials. $B M J$, v.316, p.690-693, 1998.

JUNIPER, E.F.; GUYATT, G.H.; EPSTEIN, R.S.; FERRIE, P.J.; JAESCHKE, R.; HILLER, T.K. Evaluation of impairment of health related quality of life in asthma: development of a questionnaire for use in clinical trials. Thorax, v.47, n.2, p.76-83, 1992. 
JUNIPER, E.F.; GUYATT, G.H.; WILLAN, A.; GRIFFITH, L.E. Determining a minimal important change in a diseasespecific quality of life questionnaire. J. Clin. Epidemiol., v.47, n.1, p.81-87, 1994.

JUNIPER, E.F.; PRINCE, D.B.; STAMPONE, P.A.; CREEMERS, J.P.; MOL, S.J.; FIREMAN, P. Clinically important improvements in asthma-specific quality of life, but no difference in conventional clinical indexes in patients changed from conventional beclomethasone dipropionate to approximately half the dose of extrafine beclomethasone dipropionate. Chest, v.121, n.6, p.1824-1832, 2002.

JUNIPER, E.F.; WISNIEWSKI, M.E.; COX, F.M.; EMMETT, A.H.; NIELSEN, K.E.; O'BYRNE, P.M. Relationship between quality of life and clinical status in asthma: a factor analysis. Eur. Respir. J., v.23, n.2, p.287-291, 2004.

KELLY-PIEPER, K.; PATIL, S.P.; BUSSE, P.; YANG, N.; SAMPSON, H.; LI, X.M.; WISNIVESKY, J.P.; KATTAN, M. Safety and tolerability of an antiasthma herbal Formula (ASHMI) in adult subjects with asthma: a randomized, double-blinded, placebo-controlled, dose-escalation phase I study. J. Altern. Complement. Med., v.15, n.7, p.735-743, 2009.

LEAL, L.K.; CANUTO, K.M.; SILVA COSTA, K.C.; NOBREJÚNIOR, H.V.; VASCONCELOS, S.M.; SILVEIRA, E.R.; FERREIRA, M.V.; FONTENELE, J.B.; ANDRADE, G.M.; BARROS VIANA, G.S. Effects of amburoside A and isokaempferide, polyphenols from Amburana cearensis, on rodent inflammatory processes and myeloperoxidase activity in human neutrophils. Basic. Clin. Pharmacol. Toxicol., v.104, n.3, p.198-205, 2009.

LEAL, L.K.; NECHIO, M.; SILVEIRA, E.R.; CANUTO, K.M.; FONTENELE, J.B.; RIBEIRO, R.A.; VIANA, G.S. Antiinflammatory and smooth muscle relaxant activities of the hydroalcoholic extract and chemical constituents from Amburana cearensis. A C Smith. Phytother. Res., v.17, n.4, p.335-340, 2003a.

LEAL, L.K.; NOBRE JÚNIOR, H.V.; CUNHA, G.M.; MORAES, M.O.; PESSOA, C.; OLIVEIRA, R.A.; SILVEIRA, E.R.; CANUTO, K.M.; VIANA, G.S. Amburoside A, a glucoside from Amburana cearensis, protects mesencephalic cells against 6-hydroxydopamineinduced neurotoxicity. Neurosci. Lett., v.388, n.2, p.86-90, 2005 .
LEAL, L.K.A.M.; OLIVEIRA, F.G.; FONTENELE, J.B.; FERREIRA, M.A.D.; VIANA, G.S.B. Toxicological study of the hydroalcoholic extract from Amburana cearensis in rats. Pharm. Biol., v.41, n.4, p.308-314, 2003 b.

LEAL, L.K.; PIERDONÁ, T.M.; GÓES, J.G.; FONSÊCA, K.S.; CANUTO, K.M.; SILVEIRA, E.R.; BEZERRA, A.M.; VIANA, G.S. A comparative chemical and pharmacological study of standardized extracts and vanillic acid from wild and cultivated Amburana cearensis. A.C. Smith. Phytomedicine, v.18, n.2, p.230-233, 2010.

MEGA, T.P.; SANTOS, P.M.; SOUZA-MACHADO, A.; NOBLAT, L.A.B.C.; CRUZ, A.A. Use of medicinal herbs by patients with severe asthma managed at a referral center. Braz. J. Pharm. Sci., v.47, n.3, p.643-649, 2011.

METCALFE, A.; WILLIAMS, J.; MCCHESNEY, J.; PATTEN, S.B.; JETTÉ, N. Use of complementary and alternative medicine by those with a chronic disease and the general population - results of a national population based survey. BMC Complement. Altern. Med., v.10, p.1-6, 2010.

PASSALACQUA, G.; COMPALATI, E.; SCHIAPPOLI, M.; SENNA, G. Complementary and alternative medicine for the treatment and diagnosis of asthma and allergic diseases. Monaldi Arch. Chest. Dis., v.63, n.1, p.47-54, 2005.

PATEL, Y.A.; PATEL, P.; BAVADIA, H.; DAVE, J.; TRIPATHI, C.B. A randomized, open labeled, comparative study to assess the efficacy and safety of controller medications as add on to inhaled corticosteroid and long-acting $\beta 2$ agonist in the treatment of moderate-to-severe persistent asthma. $J$. Postgrad. Med., v.56, n.4, p.270-274, 2010.

SOARES, A.K.A.; SAMPAIO, I.L.; BEZERRA, F.A.F.; MORAES, M.O.; MORAES, M.E.A. Clinical toxicology study of a herbal medicine formulation of Torresea cearensis in healthy volunteers. Rev. Bras. Plantas Med., v.9, n.2, p.55-60, 2007.

TANAKA, A.S.; SAMPAIO, M.U.; MARANGONI, S.; OLIVEIRA, B.; NOVELLO, J.C.; OLIVA, M.L., FINK, E,; SAMPAIO, C.A. Purification and primary structure determination of a Bowman-Birk trypsin inhibitor from Torresea cearensis seeds. Biol. Chem., v.378, n.3, p.273$281,1997$. 
THOMAS, M.; SHERAN, J.; SMITH, N.; FONSECA, S.; LEE, A.J.AKL1, a botanical mixture for the treatment of asthma: a randomized, double-blind, placebo-controlled, cross-over study. BMC Pulm. Med., v.7, n.4, p.1-10, 2007.

WONG, E.L.; SUNG, R.Y.; LEUNG, T.F.; WONG, Y.O.; LI, A.M.; CHEUNG, K.L.; WONG, C.K.; FOK, T.F.; LEUNG, P.C. Randomized, double-blind, placebo-controlled trial of herbal therapy for children with asthma. J. Altern. Complement Med., v.15, n.10, p.1091-1097, 2009.

WORLD HEALTH ORGANIZATION - WHO guidelines on safety monitoring of herbal medicines in pharmacovigilance systems [serial online], 2004 Available at: <http://apps. who.int/medicinedocs/index/assoc/s7148e/s7148e.pdf $>$. Acessed on: 13 jun. 2011.
ZHOU, T.N.; TANG, L.H.; HUANG, S.C.; LU, D.D.; WANG, Y.; LIU, L.F.; LAI, P.; YE, M.R. Study on the antitussive and antiasthmatic effects of Radix Fici Hirtae. Zhong. Yao Cai, v.32, n.4, p.571-574, 2009.

Received for publication on $18^{\text {th }}$ March 2012 Accepted for publication on $19^{\text {th }}$ July 2012 